\title{
Assessment of Quality of Life in the Urban Environment; Case Study: Famagusta, N. Cyprus
}

\author{
Mojdeh Nikoofam ${ }^{1, *}$, Abdollah Mobaraki \\ ${ }^{1}$ Department of Architecture, Faculty of Architecture, Eastern Mediterranean University, Turkey \\ ${ }^{2}$ Department of Architecture, Faculty of Fine Arts, Design and Architecture, Cyprus International University, Turkey
}

Received July 22, 2020; Revised September 13, 2020; Accepted September 19, 2020

\section{Cite This Paper in the following Citation Styles}

(a): [1] Mojdeh Nikoofam, Abdollah Mobaraki, "Assessment of Quality of Life in the Urban Environment; Case Study: Famagusta, N. Cyprus," Civil Engineering and Architecture, Vol. 8, No. 5, pp. 860 - 872, 2020. DOI: 10.13189/cea.2020.080513.

(b): Mojdeh Nikoofam, Abdollah Mobaraki (2020). Assessment of Quality of Life in the Urban Environment; Case Study: Famagusta, N. Cyprus. Civil Engineering and Architecture, 8(5), 860 - 872. DOI: 10.13189/cea.2020.080513.

Copyright $\bigcirc 2020$ by authors, all rights reserved. Authors agree that this article remains permanently open access under the terms of the Creative Commons Attribution License 4.0 International License

\begin{abstract}
Nowadays, the quality of life in urban environments is a controversial issue discussed in different studies as a response to many recent problems faced by cities around the world. This issue has been the center of discussion in different studies given that, based on tangible and intangible characteristics of human life. It has become one of the main concerns of every society. Since people carry out different responsibilities in urban environments, an assessment of city life is of major importance. Given that urban planning significantly impacts human health and the level of satisfaction, the study is aimed to assess the quality of life in the urban environments based on subjective and objective indicators that can be applied to improve health communication and urban vitality. For the purposes of this study, urban life in the city of Famagusta, as the most important city of North Cyprus, was investigated according to the quality of life indicator.
\end{abstract}

Keywords Quality of Life, Subjective Indicator, Objective Dimension, Urban Environment

\section{Introduction}

Given the multidimensional feature of the concept of quality of life defined in different fields and the complex implications it carries, it must be investigated using different approaches and from various theoretical viewpoints. Quality of life encompasses environmental, social, physical, economic, and psychological welfare and different experts in different fields have always attempted to handle the issues in various contexts [1]. On the other hand, the measurement of the issue is not a contemporary concern. A long time ago (384-322 BC), the philosopher Aristotle who wrote about "Living-well" and "The Good Life", also assessed that public policies are able to improve the concept. Also, considering the concept creates high competitiveness between different urban planners. Quality of life focuses on social indicators, civic livability, quality of communications, and psychological indicators, all subcategories of healthcare in the field of urban planning. When an urban designer wants to increase QOL, they generally try to define the external indicators including the level of individuals' income, good access to essential services and local resources, rather than consideration the internal conditions [2]. D. J. Forkenbrock and G. E. Weisbrod, [3] stated that urban planners make an attempt to create a healthy community and livable city by:

- Enhancing physical activity of people,

- Granting easy access to different forms of transportation, education, work, housing, healthy food, and green spaces,

- Using of clean air and water,

- Availability of chances for recreational and leisure activity,

- Improving visual characteristics of spaces, safety, and sense of belonging,

- Conservation of agricultural lands, wildlife and natural resources.

The immigration forms and attempts to increase 
urbanism directly affect QOL so the governance, urban planners and other relative communities tried to support the differences by applying the nature of job opportunities and the competitiveness of urban areas [4]. It is obvious that there is a very close relationship between QOL and the context of the urban environment where people are living. In order to determine the quality of life in the urban environment, the conditions of the environment should be measured according to the applied indicators. Additionally, if those conditions have been changed over time, it should be considered whether the changes have had an improving or deteriorating effect on QOL. People make various subjective opinions about the things which influence the quality of human life in their urban surroundings because different people might have different perceptions of this concept. Thus, the assessment of QOL in the urban environment is taken into careful consideration by various professionals in different fields especially those in urban planning. As illustrated in Figure 1, the study has designed based on subjective and objective dimensions and develop widespread relative indicators in order to assess QOL in the urban environment. Also, the assessment is examined in the case study of Famagusta.

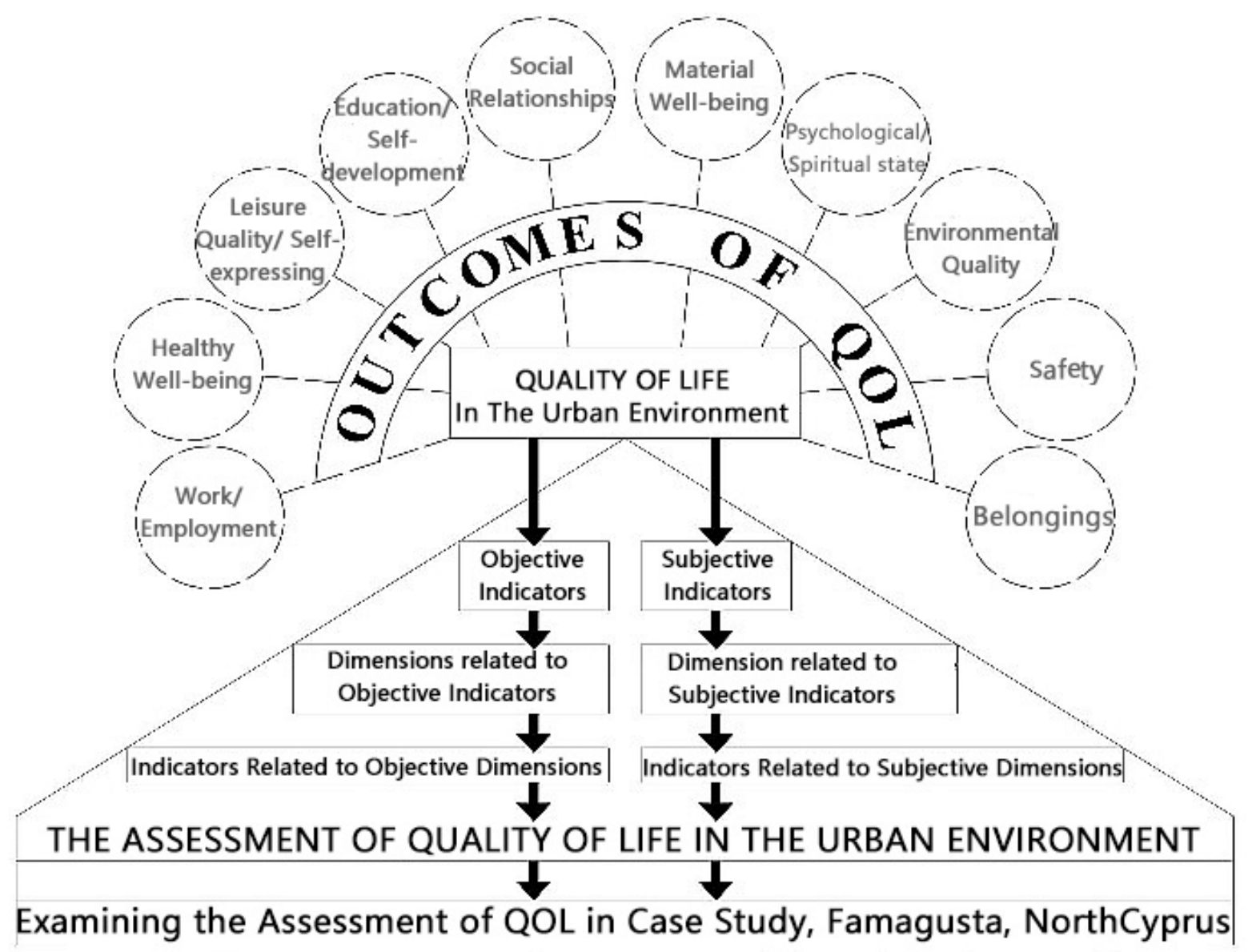

Figure 1. Structure of the Paper 


\subsection{Quality of Life}

QOL is an extremely general phrase that can have various meanings for different persons and covers different realms [5,3]. Based on P. L. Rosenbaum et al., [6], the quality of life includes three main areas that are: 1) Being refers to the physical, spiritual, and psychological components, 2) Belonging make connections between humans and social, physical, and community environments, and 3) Becoming refer to daily activities and participation in order to achieve hopes, aims, and leisure aspects. Quality of life is a multidimensional issue which is considered in a wide-range of professions, such as economic, psychological environment, urban planning, healthcare, and other fields. QOL is related to the level of individuals' happiness, and their satisfaction of different life aspects such as occupation, home, community, life, and society; as well as their economic, family, spiritual, leisure, social, emotional, and psychological well-being [7]. R. Keles [8] stated well-being reflects not only individuals' life, but also the perception of people about their lives in the area. The QOL is measured at two different levels, the individual scale and the collective or community scale. The individual scale assesses the basic requirements and expectations and the level of individuals' satisfaction about the available amenities and services. Furthermore, the collective level refers to the indicators which improve the quality of life in societies. It should be mentioned that there might be less difference in the level of satisfaction on the scales, in various communities. World Health Organization defined quality of life how humans feel about their position in life based on their culture and the value organization in which they live and how well they can achieve their expectations, targets, concerns, and standards [9].

\subsection{Quality of Life and Sustainable Development}

According to G. Moser [10], QOL as a dimension of urban planning is one of the fundamental principles of sustainable development because sustainable development is able to satisfy the requirements of the current generation without ignoring the ability of future generations to achieve their own essentials. Therefore, the achievement of individuals' requirements is not only, a precondition for sustainability, but also, creates human well-being which is one of the most important aims of achieving a high level of life quality. Environmental, social, and economic dimensions are considered to achieve sustainable development while at the same time supporting unpredictable future needs as well. Thus, the concept of QOL has a very close relationship with sustainable development that creates a balance between the dimensions which have a fundamental influence on quality of life in different scales. Sustainability should not only, ensure environmental well-being by establishing a relationship between users and the environment, but should also, ensure enhancement of individual and collective well-being. Conventionally, quality of life has been related to four issues of relative psychological study and public strategy that are: the level of individual satisfaction, health, the objective indicators of living, and sustainable development [11]. Sustainable development cannot be attained without the achievement of objective and subjective indicators of QOL.

The ideological attempt of the QOL is to improve resources for people in their surroundings to live in the best way. However, sustainable development can negatively or positively impact individuals' quality of life because while some sustainability issues are accepted by some individuals, they could be considered as unacceptable for other members of society. Consequently, it should be considered which principles of sustainable development could be acceptable for the issue. Also, when the policymakers implement the development, they should have careful attention to the potential impact it could have on some of the most fundamental indicators of QOL.



Figure 2. The Concept of QOL Has Highly Close Relationship with Sustainable Development 


\subsection{Quality of Life and Urban Environments}

The researchers in social science and the environmental planning professions have been investigating the quality of life in the subjective and objective dimensions. Urban environment can be defined as having unbuilt or natural, built or physical, and intangible or socio-cultural dimensions $[12,13]$. Additionally, different environments have allocated various characteristics to each dimension. Although, studies about quality of life have tried to consider the individuals' attributes, for example, their occupation, health, age, and human relationships. People are spending their lives in places with particular characteristics which are formed based on that specific environment, which might be limited at different levels or scales such as a housing unite neighbourhood or local district, a metropolitan, and a state. Therefore, people's living environment can have an important influence on their quality of life according to their characters, scales, etc. In order to design an urban environment that would enhance the level of satisfaction for the users, the urban planners initially examine the connection between urban environment and the received quality of life. People have different perceptions about life in an urban environment and the level of perception reflected quality of life for its residents. Many urban studies indicate the important characteristics of urban environment for achieving the positive contributions which increase the quality of human life in their environment. For instance, in order to improve the quality of human life, contemporary approaches of urban planning are applied to serve the most important requirement of the people who are living and working in that environment [14-16]. J. I. Carruthers and B. Mundy [17] considered the New Urbanism (NU) that was established by a group of different scholars in Congress for the New Urbanism (CNU). They tried to create friendly pedestrian environments in neighbourhoods to decrease car-dependency by using "Transit-Oriented Developments" (TOD) and "Neo-traditional Town" as the main theories for the movement. The main goal of this movement was achieving a high quality of life by applying the principles listed below [14,18,19]:

- Well-structured cities, and neighbourhoods with well distinguishable centres and edges,

- Interconnected streets with friendly sidewalks and cyclists, suitable and adequate parking spaces and garages to avoid car-dependency,

- Compact development in order to protect farmland, wildlife and environmentally sensitive areas (survive biodiversity),
- Designing mix land uses instead of single use and segregated functions (mix of activities),

- Creating a variety of housing typologies and street to create a coherent urban form,

- Constructed well designed civic constructions and public gathering spaces,

- Improving the quality of greens or parks and their conservation to connect and define neighbourhoods and cities with an increased sense of belonging,

- Respect to local history and regional character with well architectural design.

In order to develop quality of human life in the urban environment, New Urbanism can achieve different indicators of quality of life by using the principles illustrated in Figure 4.

In addition, Smart Growth (SG) is a movement focusing on promoting compact design, diversity, and walkability to decrease car-dependency and land-consumptive. As can be seen in Figure 3, the most prominent indicator of the movement is improving quality of life. As it is mentioned by Song Y. and G. J. Knaap [20], Smart Growth is able to increase the quality of life by adopting community, economy, and environment without ignoring all traditional theories.

The movement attempt to define all indicators of QOL according to the listed principle (See Figure 4). They tried to achieve the environmental characteristics by protecting open spaces, farmland or natural properties and critical environmental areas [21]. Also providing advantages from adopting compact building design, well-organized infrastructure and mixed land use are applied as physical characteristics to achieve quality of life. Moreover, the movement is based on walkable trails and different range of transportation choices to increase the level of urban mobility in cities. In addition, fostering diversity and creating attractive communities with a strong sense of place-attachment for all users provide social justice and psychological indicators which increase the level of quality of human life in urban environment [14,22-24]. The pioneers of Smart Growth decided to develop decision-making about urban legislation to improve cost-effectiveness, and equal rights in political and economic theories for enhancing QOL in urban surrounding $[14,22,25]$. Therefore, the mentioned example illustrates that the design of the urban environment has a different influence on various settlements. The designers always with an excellent design try to increase economic stability, social health and being responsible toward environmental and natural properties throughout suitable policies or good governance which have a fundamental impact on quality of individuals' life. 


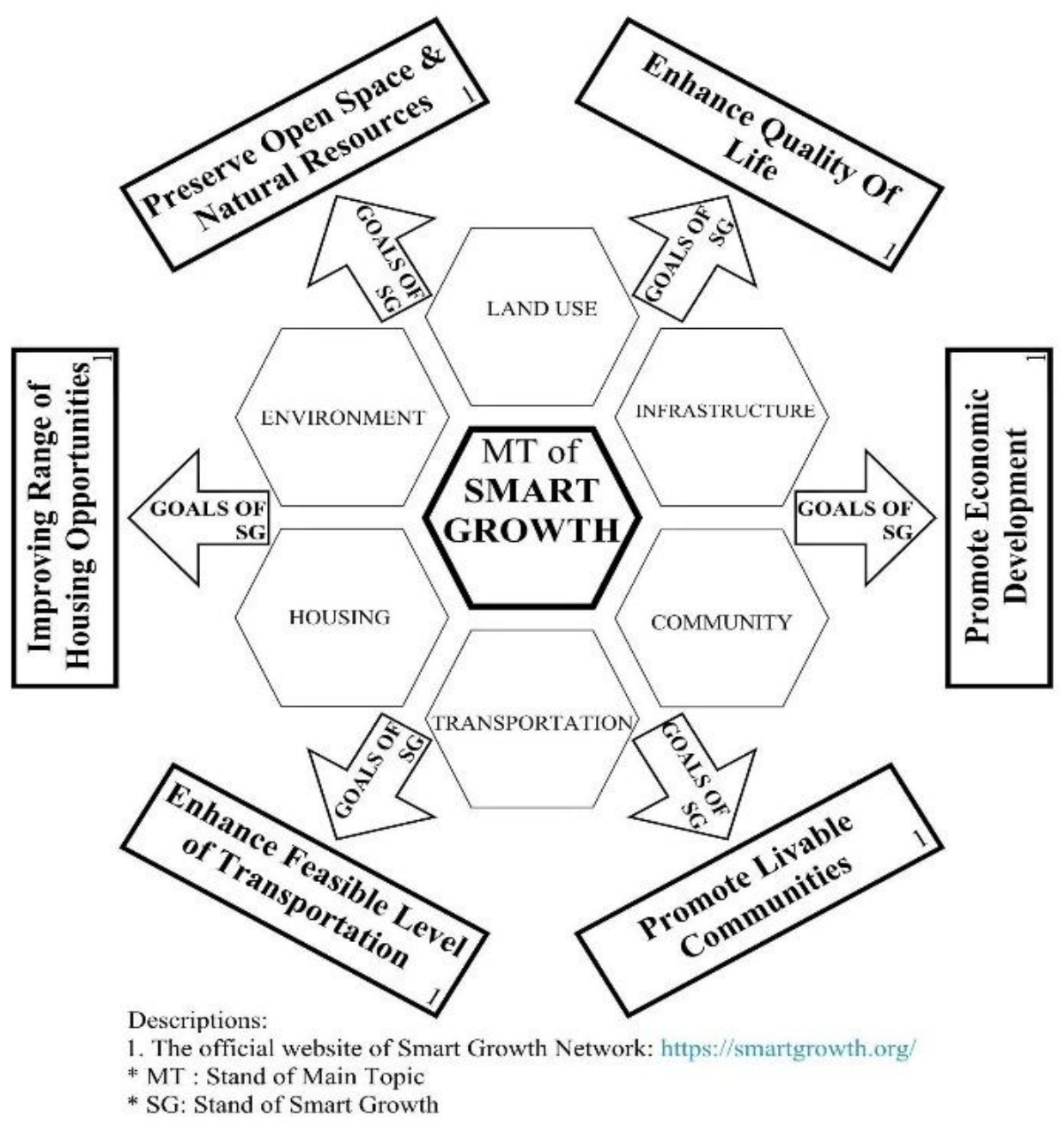

Figure 3. The Goals of Smart Growth

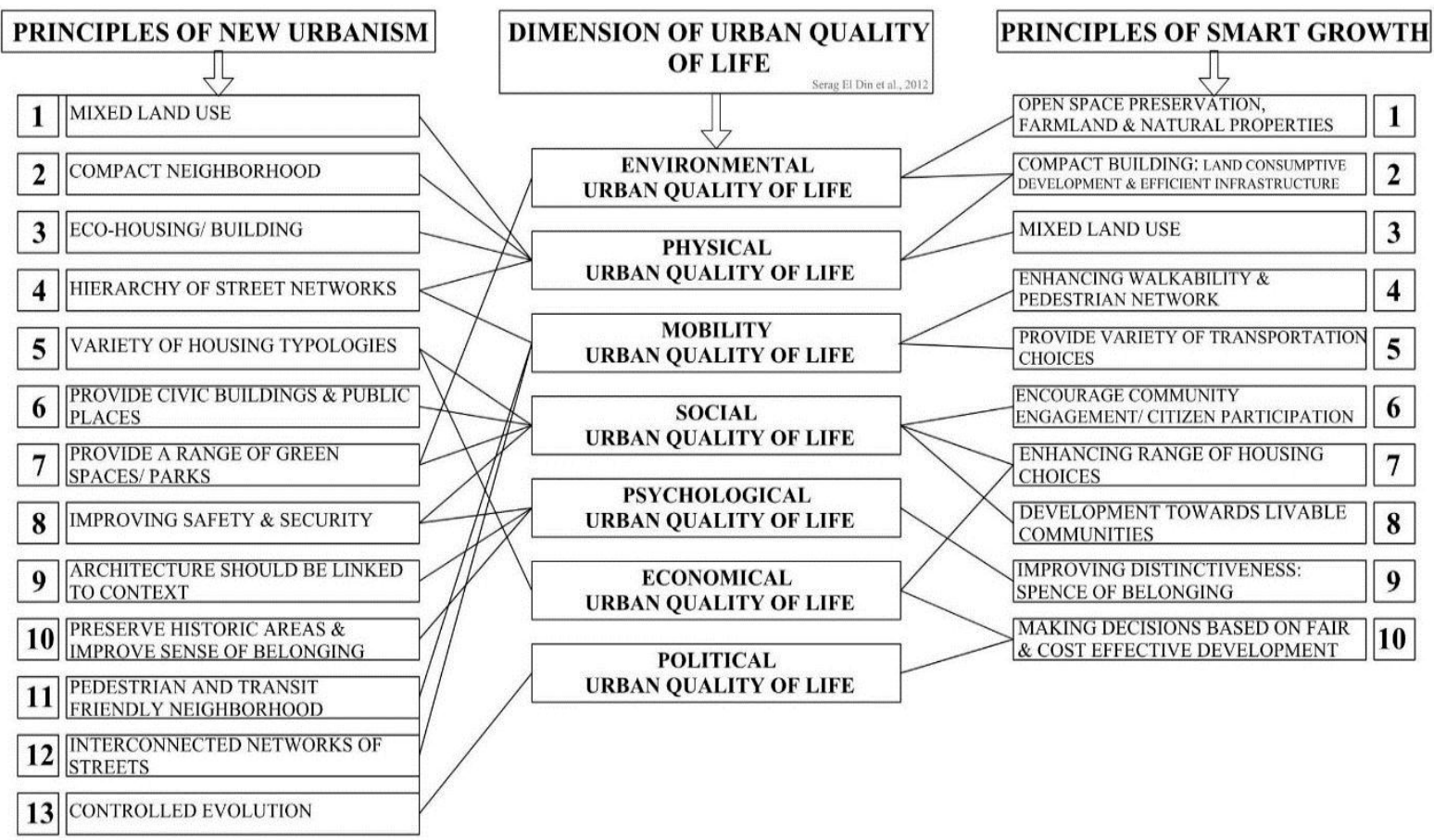

Figure 4. The Relation between the Dimensions of QOL and the Principles of NU and SG 


\section{Investigating Quality of Life in Urban Environment}

Two main approaches are defined by E. Diener and E. Suh [26] to measure the QOL. The first approach refers to objective indicators which are measured according to the social characteristics of the society, for example, the level of individuals' education, crime statistics, and the rate of unemployment. The second has measured the subjective indicators which are related to the individuals' experience about their life, well-being and life satisfaction or persons' happiness. In addition, R. W. Marans and R. Stimson [27] measured QOL according to the following approaches: 1) The objective approaches, connected to social indicators study. This approach is limited to analyzing aggregate information at different geographic locations collected in official governmental documents, including the census; 2) The subjective indicators provide individual or disaggregate data which focus on the peoples' evaluations, or assessments of QOL in general, as well as, the assessment of urban environments in particular; 3) The behavioral indicators include space utility, and the availability of participation, facilities, and amenities in our environment (Figure 5).

Moreover, as it is revealed in Figure 5, quality of life in urban environments is investigated based on connecting different main dimensions including a) environmental characteristics, that refer to the natural aspects of the districts or neighbourhood; b) physical characteristics, that refers to land use management, urban context, facilities or amenities, and infrastructure; c) Urban mobility, which encompasses accessibility, transportation and traffic issues; d) Social characteristics, which contain the indicators related to individuals' interaction, and participation of citizens ; e) Psychological indicators which discuss the feeling of citizens towards their environment like the sense of belonging or identity; f) Economical characteristics, that refer to the economic indicators in cities like measurement life cycle of cost; and g) political dimension, that related to the urban policies which are able to support the dimension of QOL in urban environment [25].

The present study has defined the quality of life in two dimensions. The objective QOL falls under nine categories of indicators consisting of social, environmental, economic, physical, cultural, political characteristics, urban mobility, infrastructural indicators, and demography (Figure 5, Table 1) $[25,28-31]$. In addition, the objective indicators are the visual characteristics and place identity or perception of urban space, also, social characteristics can define as both, subjective and objective indicators (Figure 5, Table 1) [28,30-32].


Figure 5. The Present Study Has Defined Dimension of QOL in Urban Environment Based On Different Studies 
Table 1. The Indicators and Principles of QOL in Urban Environment

\begin{tabular}{|c|c|c|c|}
\hline & & & Air Quality: Quality of atmosphere, The health quality of air, Prevention of air pollution \\
\hline & & & Water Quality: Quality of drinking water, Quality of water edges, Management of water consumption \\
\hline & & & Land Quality: Remediation of soil contamination, Biodiversity, Ecological footprints \\
\hline & & $\begin{array}{l}\text { Environmental } \\
\text { or Natural }\end{array}$ & $\begin{array}{l}\text { Quality of Materials: Renewable, Recycle and Non-hazardous materials with respect to health of people } \\
\text { and environment }\end{array}$ \\
\hline & & & $\begin{array}{l}\text { Quality of Urban Environment: Providing parks \& natural landscape, Comfortable outdoor temperature, } \\
\text { Decrease sound pollution, Well-lit public open spaces, and Reduction of unpleasant odor }\end{array}$ \\
\hline & & & Energy Use: Use of Renewable energy, Energy efficiency \\
\hline & & & Recycling \& Waste Management: Waste collection and disposal, waste recycling \\
\hline & & & $\begin{array}{l}\text { Land Use Management: Mixed land use, Urban facilities and amenities, Effective land-consumptive like } \\
\text { land reuse }\end{array}$ \\
\hline & & Physical & Urban Form: Compact city, Density \\
\hline & & Characteristics & $\begin{array}{c}\text { Urban Layout: Street \& square network, Building block and proportion (building line, well integrated car } \\
\text { parking, building height-to-width ratio) }\end{array}$ \\
\hline & & & $\begin{array}{l}\text { Quality of House \& Building: Building \& Housing quality according to durability, adaptability, different } \\
\text { type of houses, condition, overcrowding average, access to indoor facilities, access to infrastructure }\end{array}$ \\
\hline & & & Accessibility: Pedestrian quality, Connectivity, Movement with respect to the users' ability \\
\hline & 馬 & & Walkability and Cycling: Walkable network, Cycling ability of network and facilities, Traffic calming \\
\hline & $\underset{0}{\tilde{J}}$ & Urban Mobility & $\begin{array}{l}\text { Public Transportation: Available choices of transportation, Adequate and accessible transportation, Easy } \\
\text { access to the facilities }\end{array}$ \\
\hline &. $\bar{E}$ & & Traffic Load: Traffic congestion, Management of transportation demand (TDM) \\
\hline 㭊 & $\overline{0}$ & $\begin{array}{c}\text { Cultural } \\
\text { Characteristics }\end{array}$ & $\begin{array}{l}\text { Cultural Activities: Number of libraries, museum, theaters } \\
\text { Cultural Heritage: Conservation of historical environment }\end{array}$ \\
\hline 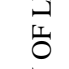 & & $\begin{array}{l}\text { Infrastructural } \\
\text { Indicators }\end{array}$ & Availability of health centers, clinics, hospitals and sanitation \\
\hline 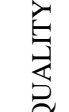 & & Demography & $\begin{array}{c}\text { Measuring the number of older and youth people } \\
\text { Immigration statistics } \\
\text { Rate of population }\end{array}$ \\
\hline & & $\begin{array}{c}\text { Economic } \\
\text { Characteristics }\end{array}$ & $\begin{array}{l}\text { Affordable Housing, } \\
\text { Easy Access or proximity to health center, employment, education, all services. } \\
\text { Energy Cost } \\
\text { Land Capacity: balancing the cost differences between land values and individual income, } \\
\text { Passive Solar System: Passive solar heating system, natural cooling techniques and systems for natural } \\
\text { lighting create comfortable temperature and decrease life cycle of cost. }\end{array}$ \\
\hline & & $\begin{array}{c}\text { Political } \\
\text { Characteristics }\end{array}$ & $\begin{array}{l}\text { Urban Strategies \& policies, } \\
\text { Urban fair rights, } \\
\text { Responsive urban legislation, } \\
\text { Strong urban management } \\
\text { Steady supervision }\end{array}$ \\
\hline & & & Social Justice: Equal access to affordable building, Equal access to all services \\
\hline & & Characteristics & Inclusive Communities: Accessibility for disable people, Comfort, Safety \\
\hline & & & Social Participation: Considering users in Planning process, Increasing diversity. \\
\hline & & $\begin{array}{c}\text { Social } \\
\text { Characteristics } \\
\end{array}$ & Behavioral Performance: Public awareness, Urban stability, Urban vitality \\
\hline & & & Urban Image: enhancing urban legibility such as constructing landmarks, distinguishable paths and district \\
\hline & 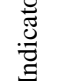 & Place Identity & $\begin{array}{l}\text { Responsive Design: Respecting to the identity of the specified city or district, Protecting of heritage and } \\
\text { historical sites such as contextual design }\end{array}$ \\
\hline & $\stackrel{0}{D}$ & & $\begin{array}{l}\text { Personalization: Indicating the function of a space, Applying the excellent design that users can adapt with } \\
\text { their environment }\end{array}$ \\
\hline & $\ddot{2}$ & & Urban Attractiveness \\
\hline & & $\begin{array}{c}\text { Visual } \\
\text { Characteristics }\end{array}$ & Urban Distinctiveness \\
\hline & & & Management and Maintenance \\
\hline
\end{tabular}




\subsection{Objective Indicators}

These indicators are underpinned on quantitative data of urban environment indicators which are reflected in the fundamental requirement of the citizens and enhance the quality of urban life. Environmental or natural properties are the central concern of urban planning that can contribute to the enhancement of human health in urban life (See Table 1) [33,34], because the indicators increase the quality of the air we are breathing, our drinking water, organization of our habitat and the land we are living on. Quality of the air is the essential consideration in urban areas for human health. In order to improve the quality of air, World Health Organization (WHO) has determined the atmospheric quality with decreasing six air pollutants such as $\mathrm{CO}^{2}, \mathrm{CO}, \mathrm{SO}^{2}, \mathrm{NO}^{2}, \mathrm{O}^{3}$, and etc [35]. These gases have a high tendency in air pollution and increase urban health. Hence, air pollution leads to different types of dangerous diseases, making short life expectancy, and increasing the rate of death in cities. The health quality of air is suggested because air pollution has become one of the main causes of many problems and a threat to human health in recent years. Consequently, the prevention of air pollution becomes the central concern of urban policies. Thus, the provision of landscapes, plants, trees and green buffer areas can not only, decrease air pollution and increase $\mathrm{O}^{2}$, which we are breathing, but also, provide a suitable bed for health communication and activities [36]. The quality of water is another important indicator that has a significant effect on human health. The quality of drinking water, quality of water edges and management of water consumption is considered to increase the quality of water (Table 1) [30,31]. Furthermore, quality of land can be increased by regenerating contaminated ground, increasing biodiversity, and ecological footprint (Table 1) [30,37]. Other factors which have a deep impact on our environment are attributed to the quality of materials. The materials should be considered according to their impact on human health and health of environment so designers should select non-hazardous, renewable and recyclable materials (Table 1) [36,37]. Moreover, assessment of the local environment is a fundamental indicator in urban planning that can support comfortable conditions in outdoor spaces hence, leading to an increase in the individuals' participation (Table 1) [31,38]. Providing natural landscapes and parks, comfortable outdoor temperature, decreasing sound pollution, well-lit public open spaces, and reduction of unpleasant odor are the important factors that enhance the quality of local environments (Table 1) [30,40]. Controlling energy use is the other indicator that has a positive effect on environmental and economic characteristics. The final indicator is waste management and recycling. Waste contains solid, gas and liquid nature that can affect human and environmental health (Table 1) $[30,31,37]$. The second indicator of quality of life is related to physical characteristics. This indicator enhances human activity and communication in urban environments. The principles of the indicator consist of (Table 1): a) Considering land use management by increasing mixed land use, the urban facilities and amenities, effective use of land like land reuse; b) Considering urban form for optimizing density; c) Making attention to urban layout such as proportion of building block, street and square network; d) Considering the quality of housing and building by increasing adaptability, durability, access to indoor facilities, access to infrastructure and different types of residential units $[25,31,37,41]$.

The third indicator is related to the quality of urban mobility which encourages people to travel and participate in socio-cultural life or activities. The indicator of the characteristics is listed in following: 1) Accessibility increase pedestrian quality, connectivity, and movement with respect to the users' ability; 2) Walkability and cycling in urban networks; 3) Public transportation: increasing choices of transportation, adequate and accessible transportation, easy access to the facilities; 4) Traffic load is the other factor that has a deep effect on the human well-being (Table 1) [30,39,42]. Cultural characteristics are the other indicators of QOL. The number of libraries, museums, and theatres as cultural life activities and conservation of historical environment as cultural heritage can reflect the QOL in the urban environment (Table 1) [29,43]. Measuring the infrastructural indicators of the society is another subjective indicator that has a fundamental impact on the quality of life in built environments. These include the number of health centers, clinics, hospitals and levels of sanitation (Table 1) [29]. Furthermore, measuring the number of older and youth people, immigration and rate of population as demographic consideration is the most important indicator that should be considered in the urban environment to provide suitable facilities to enhance QOL in the area (Table 1) [27,29]. The sixth indicator is related to the economic consideration which provides information regarding job opportunities and local businesses (Table 1). As can be seen, the situation of urban economic has a significant influence on designing the exterior and interior of the built environments [44]. On the other hand, the designer has a deep effect on the indicator for their user by improving affordability in various scales such as improving proximity and easy access to primary and essential needs such as school, health center, job and all urban services, affordable housing, and decreasing energy cost in buildings by considering energy use because all persons should have fair right to access to these essential $[30,37,45]$. Also, land and rent price has a deep effect on low- and middle-income households that land capacity improves the balance between land values and income level of people. Moreover, the use of passive techniques for natural cooling, heating, and lighting is the main aims of passive solar schemes that improve comfortable temperature and lessening cost of life cycle (Table 1) $[30,45]$. In addition, governance and political concern is the most important factor in achieving higher level of life 
quality (Table 1) $[25,31,48]$. The urban policies or strategies, urban fair rights, responsive urban legislation, strong urban management and steady supervision are the most important parameters for enhancing QOL as political characteristics. Additionally, the last indicator can be defined as both, subjective and objective indicators because the social characteristics can reflect quantitative and qualitative indicators (Table 1) [30]. Consideration of social indicators increases social equity and justice, inclusive communities, livability, social interaction and social connectedness in the cities (Table 1) $[30,31,39,46-48]$.

\subsection{Subjective Indicators}

The subjective indicators of QOL focus on perception, level of human satisfaction, well-being, opinions and feeling of individual and community scale of human beings $[26,32,49,50]$. The study defines subjective indicators by enhancing the sense of belonging or place-attachment and considering visual characteristics. Identity of place is one of the important proposes of creating a vivid street to satisfy all users and provide means of cohesive communication. The principles of sustaining place identity are related to (Table 1):

- Consider urban image for enhancing urban legibility such as constructing landmarks, distinguishable paths and districts;

- Responsive and contextual design for respecting to the identity of the specified city or district and protecting of heritage and historical sites;

- Personalization by indicating the function of a space, applying the excellent design that users can adapt to their environment.

Visual characteristics of a place can have a deep effect on quality of life in the environment [51,52]. The principles of the characteristics are: 1) urban attractiveness; 2) urban distinctiveness; 3 ) management and maintenance are the other responsibility for enhancing urban morphology (Table 1). The above-mentioned principles can increase cleanliness, comfort, safety and inclusivity in our environment that the indicators have a fundamental influence in enhancing the quality of urban life by increasing community and urban livability.

\section{Case Study}

Famagusta is the second largest town of Turkish Republic of Northern Cyprus that lies on the east of the Mediterranean Sea, as historic core and harbor [53].

According to N. Doratli [54], the history of Famagusta is divided into seven particular periods. The first one lies between 648-1192 AD when the eldest settlements were founded. The Lusignan period lasted from 1192 to 1489. During the period, Famagusta's Eastern Mediterranean area, its harbor and the walls were improved. The time period between the Lusignan period until 1571 was called the Venetian period during which differences in socio-cultural life had a deep influence on the architectural style and design of their environment. During 1571-1878 Famagusta was occupied by Ottoman and the era was named the Ottoman. The city was transferred to a modern city in the British time (1878-1960). Additionally, the sixth period continued between 1960 to 1974 with 1974 being the last one [41,53]. According to TRNC 2006 Population $\&$ Dwelling Census, the city consists of 35,453 people. Before the division of the island in 1975, the city was well known as a regional and tourism center. These days, Famagusta houses a variety of residents including EMU university staff and students from different countries, local Turkish Cypriots, and immigrants who have come from the south part in 1974 and from different parts of Turkey.

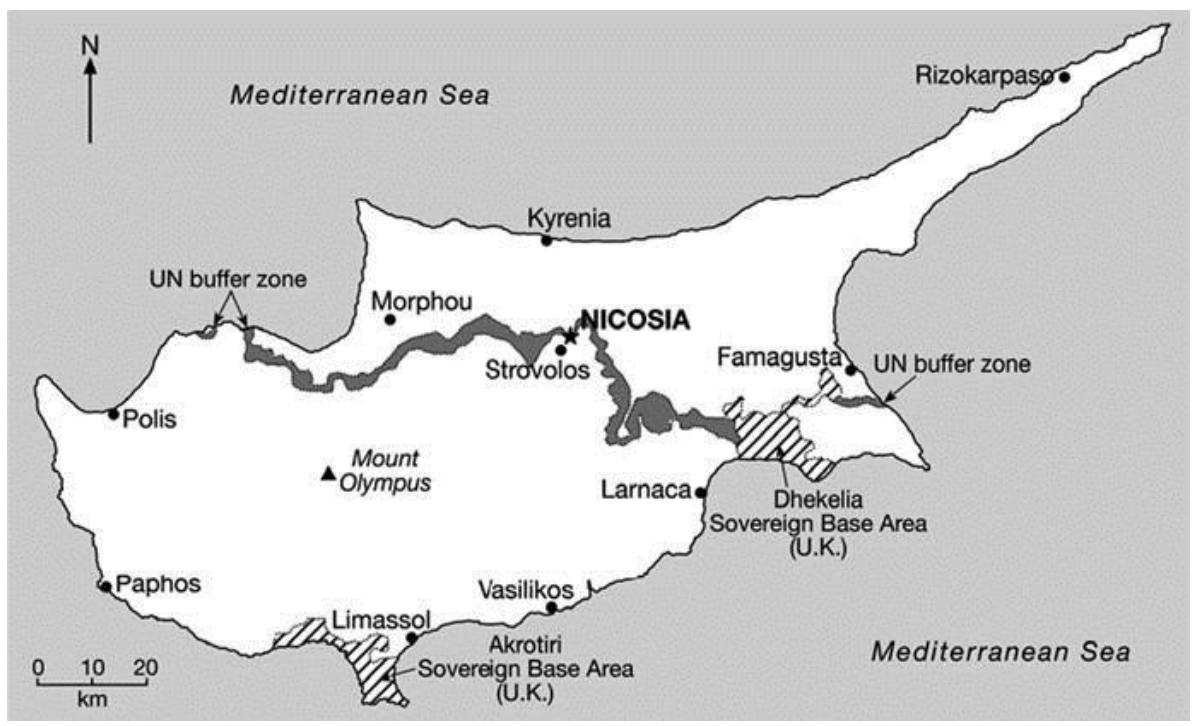

Figure 6. Map of the Cyprus showing location of Famagusta (Oktay, 2007) 
Table 2. Assessment of the Indicators QOL in Famagusta

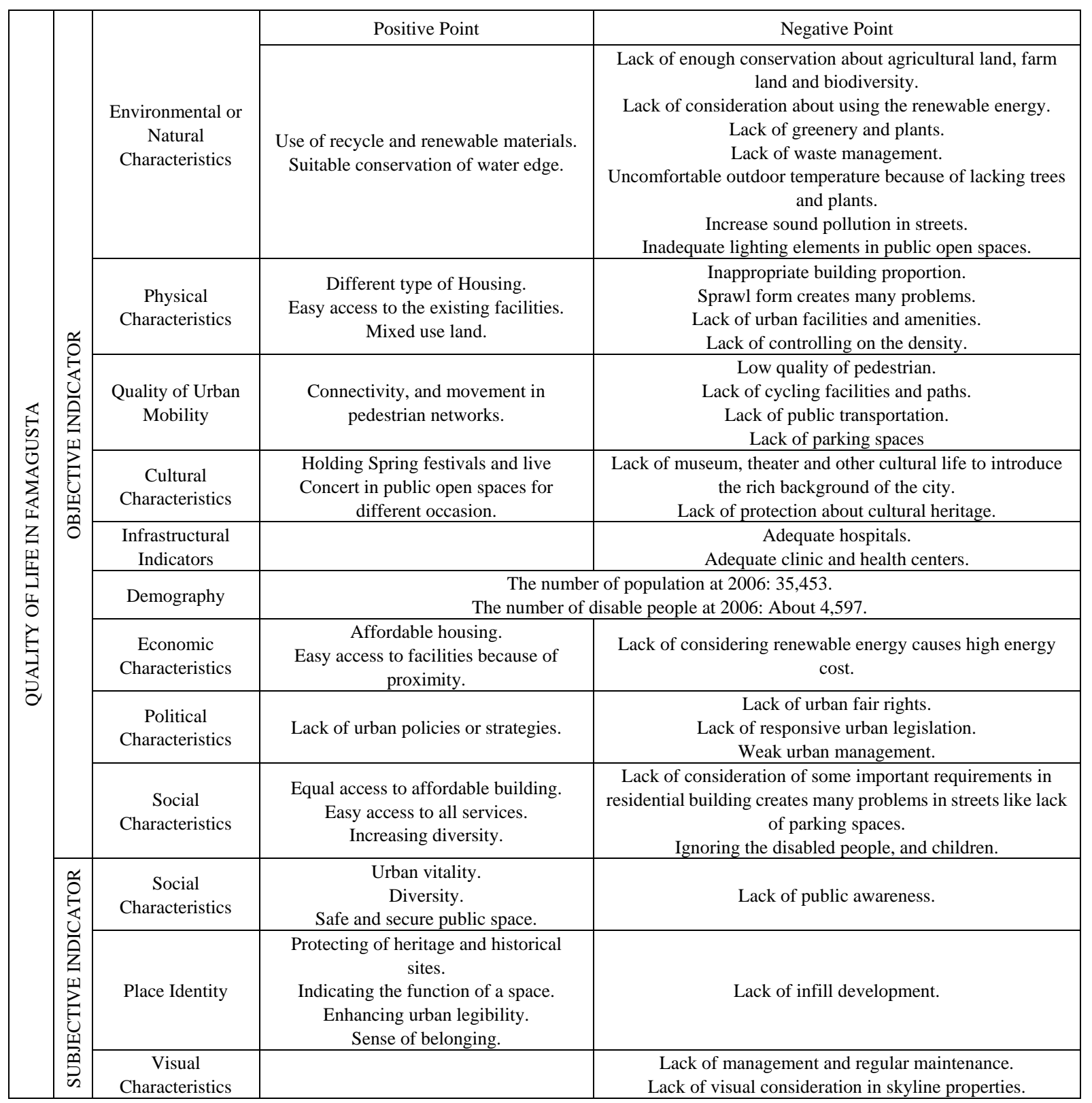

Nowadays, it is so clear Fmagusta have faced with immediate or uncontrolled urban development and incompatible land uses. Lost and empty spaces between buildings are the most negative aspect of the unplanned urban development that decreases the visual appropriateness of the city [50-52,55]. Because the city has an important potential effect on social and economic characteristics in North Cyprus, the assessment of quality of life for its inhabitants is the center of concern in urban policies. According to the above mentioned subjective and objective indicators of quality of life, the city has a safe or secure environment, mix land uses for different users, various types of housing, affordability, friendly neighbourhoods, diversity, different shopping facilities and a strong economy. However, unprotected natural and environmental properties, the sprawl form of the city, ineffective environmental problem solving, and inappropriate building design have increased the negative effect on the environmental and physical characteristics of the city $[40,54]$. Lack of public transportation, parking spaces, important infrastructure, and inaccessible streets, little sense of historical values, lack of cultural amenities, lack of park and greenery spaces in different neighbourhoods are the other important problems that have deeply affected the QOL in the town. Generally, the majority of the population are dissatisfied with the maintenance of roads, sidewalks, recreational facilities, noise level of streets, traffic volume and availability of public transportation in Famagusta [42,50,56,57]. However, the high level of security and sense of belonging 
are the most important indicators that can increase individual well-being, level of satisfaction and QOL in the city. The government and policies should consider the problems of objective indicators to enrich the quality of life. Table 2 illustrates the negative and positive aspects of objective dimensions and subjective indicators which are mentioned in this study.

\section{Conclusions}

Quality of life is a fundamental consideration in urban planning that can help overcome the problems of cities and enhance the level of human satisfaction. The study categorized the important approaches which can significantly enhance the QOL in the urban environments. The research collected the objective and subjective indicators for different living environments. The objective dimension of the QOL takes nine indicators into consideration to help designers enhance the quality of life for different urban environment inhabitants. Environmental or natural, physical, cultural, economic, political and social characteristics, demography, infrastructural indicators, quality of urban mobility are considered as objective dimensions of QOL in the urban environments. Meanwhile, as previously mentioned, the social characteristics are defined as both, subjective and objective indicators because the built environment and individual behavior can contribute to the concept. The features of the built environment refer to the quantitative indicators of the society but the behavioral characteristics reflect the quality of individuals' perception of wellbeing. Also, the subjective indicator is defined as the identity of a place and its visual characteristics which have a fundamental influence on the QOL. Famagusta, as one of the most important cities in North Cyprus, is evaluated according to these indicators. As it is mentioned in Table 2, although people are not pleased or satisfied with the maintenance and management of the trails, the safe urban environment and sense of place attachment enhances individual well-being, level of satisfaction, and the quality of life in the city. Furthermore, mixed land uses, familiar or friendly environment, diversity, easy access to different facilities, different types of housing, and cultural aspects of the city help increase the level of satisfaction. However, the following solutions can be utilized to solve the existing problems:

- Improve sustainable public transportation, parking spaces,

- Sustainable street networks with respect to the individual abilities of all people like disabled people, and, improving street maintenance, and reducing traffic density.

- Planting trees or creating green belts to increase comfortable outdoor temperature and decrease sound pollution,
- Increase the compaction in urban design development,

- $\quad$ Prioritizing and addressing the needs of people e.g. proper recreational facilities, available and accessible parks, shopping facilities, and schools,

- These results recommend that the future policies related to residential quarters and buildings should consider required full services e.g. parks, parking spaces, and other necessary services that are easily available and accessible.

- Use of strategic planning with long term decision-making and problem-solving that control sprawl form of the city and create healthier living areas.

\section{REFERENCES}

[1] G. Li, \& Q. Weng. Measuring the quality of life in city of Indianapolis by integration of remote sensing and census data. International Journal of Remote Sensing, 28(2), 249-267, 2007. https://doi.org/10.1080/0143116060073562 4

[2] A. Pichardo-Muñiz. The role of diseconomies of transportation and public safety problems in the measurement of urban quality of life. Applied Research in Quality of Life, 6(4), 363-386, 2011. https://doi.org/10.1007 /s11482-010-9134-2

[3] D. J. Forkenbrock \& G. E. Weisbrod. NCHRP Report 456: Guidebook for assessing the social and economic effects of transportation projects (No. Project B25-19 FY'99), 2001. http://onlinepubs.trb.org/onlinepubs/nchrp/nchrp_rpt_456-a .pdf

[4] M. J. Sirgy, D. R. Rahtz, M. Cicic, \& R. Underwood. A method for assessing residents' satisfaction with community-based services: a quality-of-life perspective. Social Indicators Research, 49(3), 279-316, 2000. https://doi.org/10.1023/a:1006990718673

[5] M. R Hagerty, R. Cummins, A. L. Ferriss, K. Land, A. C Michalos, M. Peterson, ... \& J. Vogel. Quality of life indexes for national policy: Review and agenda for research. Bulletin of Sociological Methodology/Bulletin de Méthodologie Sociologique, 71(1), 58-78, 2001. https://doi.org/10.1177/0 75910630107100104

[6] P. L. Rosenbaum, M. H. Livingston, R. J. Palisano, B. E. Galuppi \& D. J. Russell. Quality of life and health - related quality of life of adolescents with cerebral palsy. Developmental Medicine \& Child Neurology, 49(7), 516-521, 2007. https://doi.org/10.1111/j.1469-8749.2007.00516.x

[7] A. C. Michalos, M. J. Sirgy \& R. J. Estes. Introducing the Official Journal of the International Society for Quality-of-Life Studies: Applied Research in Quality of Life (ARQOL). Applied research in quality of life, 1(1), 1-3, 2006. https://doi.org/10.1007/s11482-006-9013-z

[8] R. Keles. The quality of life and the environment. Procedia-Social and Behavioral Sciences, 35, 23-32, 2012. 
https://doi.org/10.1016/j.sbspro.2012.02.059

[9] K. Feder, D. S. Michaud, S. E. Keith, S. A. Voicescu, L. Marro, J. Than, ... \& C. Whelan. An assessment of quality of life using the WHOQOL-BREF among participants living in the vicinity of wind turbines. Environmental research, 142, 227-238, 2015. https://doi.org/10.1016/j.envres.2015.06.043

[10] G. Moser. Quality of life and sustainability: Toward personenvironment congruity. Journal of Environmental Psychology, 29(3), 351-357, 2009.https://doi.org/10.1016/j. jenvp.2009.02.002

[11] D. Uzzell \& G. Moser. On the quality of life of environments. European Review of Applied Psychology, 56(1), 1-4, 2006. https://doi.org/10.1016/j.erap.2005.02.007

[12] R. W. Marans. Understanding environmental quality through quality of life studies: the 2001 DAS and its use of subjective and objective indicators. Landscape and Urban Planning, 65(1-2), 73-83, 2003. https://doi.org/10.1016/S01 69-2046(02)00239-6

[13] H. Türkoğlu, F. Bölen, P. K. Baran \& F. Terzi. Measuring quality of urban life in Istanbul. In Investigating quality of urban life (pp. 209-231). Springer, Dordrecht, 2011. https://doi.org/10.1007/978-94-007-1742-8_9

[14] W. M. Wey \& J. Hsu. New urbanism and smart growth: Toward achieving a smart National Taipei University District. Habitat International, 42, 164-174, 2014. https://d oi.org/10.1016/j.habitatint.2013.12.001

[15] G. Knaap \& E. Talen. New urbanism and smart growth: A few words from the academy. International Regional Science Review, 28(2), 107-118, 2005. https://doi.org/10.11 $77 / 0160017604273621$

[16] A. Downs. Smart growth: Why we discuss it more than we do it. Journal of the American Planning Association, 71(4), 367-378, 2005.https://doi.org/10.5822/978-1-61091-491-8_ 47

[17] J. I. Carruthers \& B. Mundy (Eds.). Environmental valuation: Interregional and intraregional perspectives. Ashgate Publishing, Ltd., 2006. https://doi.org/10.4324/9781351158 961

[18] Congress for the New Urbanism. Charter of the new urbanism. 2002. Online available: http://www.cnu.org/chart er.

[19] K. Day. New urbanism and the challenges of designing for diversity. Journal of Planning Education and research, 23(1), 83-95, 2003. https://doi.org/10.1177/0739456x03255 424

[20] Y. Song \& G. J. Knaap. New urbanism and housing values: a disaggregate assessment. Journal of Urban Economics, 54(2), 218-238, 2003. https://doi.org/10.1016/s0094-1190(0 3)00059-7

[21] A. Gospodini \& S. Manika. Conceptualising 'Smart' and 'Green' Public Open Spaces; Investigating Redesign Patterns for Greek Cities. Civil Engineering and Architecture, 8(3): 371-378, 2020. https://doi.org/10.13189/cea.2020.080322

[22] P. La Greca, L. Barbarossa, M. Ignaccolo, G. Inturri \& F. Martinico. The density dilemma. A proposal for introducing smart growth principles in a sprawling settlement within Catania Metropolitan Area. Cities, 28(6), 527-535, 2011. https://doi.org/10.1016/j.cities.2011.06.009

[23] L. Ye, S. Mandpe \& P. B. Meyer. What is "smart growth?"-Really?. Journal of Planning Literature, 19(3), 301-315, 2005. https://doi.org/10.1177/0885412204271668

[24] B. LEE \& E. HAARHOFF. Urban Growth, Liveability and Quality Urban Design: Questions about the efficacy of urban planning systems in Auckland, New Zealand. Journal of Contemporary Urban Affairs, 2(2), 12-23, 2017. https://doi.org/10.25034/ijcua.2018.3667

[25] H. Serag El Din, A. Shalaby, H. E. Farouh \& S. A. Elariane. Principles of urban quality of life for a neighborhood. Hbrc Journal, 9(1), 86-92, 2013. https://doi.org/10.1016/j.hbrcj.2 013.02.007

[26] E. Diener, \& E. Suh. Measuring quality of life: Economic, social, and subjective indicators. Social indicators research, 40(1-2), 189-216, 1997. https://link.springer.com/content/p df/10.1023/A:1006859511756.pdf

[27] R. W. Marans \& R. Stimson. An overview of quality of urban life. In Investigating quality of urban life (pp. 1-29). Springer, Dordrecht, 2011. https://doi.org/10.1007/978-94007-1742-8_1

[28] L. L. C. Mercer. Quality of Living Rankings,”. 2016. https://www.mercer.com/newsroom/2016-quality-of-livingsurvey.html

[29] A. M. Feneri, D. Vagiona \& N. Karanikolas. Measuring quality of life (QoL) in urban environment: An integrated approach. Cest2013, Athens, Greece, 2013.http://ikee.lib.au th.gr/record/273209/files/\%CE\%93_49.pdf

[30] S. A. El Ariane. Neighborhood urban quality of life: Guidelines for urban planning and development of new assessment tool. 2012.http://www.cpas-egypt.com/pdf/Sara AbdelMoneimElAriane/Ph.D/Neighborhood\%20Urban\%20 Quality\%20of\%20Life.pdf

[31] K. Jamieson. Quality of life in twelve of New Zealand's cities 2007. Christchurch, New Zealand: New Zealand Government, 2007. http://www.qualityoflifeproject.govt.nz/ pdfs/2007/Quality_of_Life_2007.pdf

[32] A. Beer \& C. Higgins. Environmental planning for site development: a manual for sustainable local planning and design. Routledge, 2004. https://doi.org/10.4324/97802036 39108

[33] M. Nikoofam \& A. Mobaraki. In Pursuit of Sustainable Strategic Long-term Planning Throughout

Meta-postmodernism as New Perspective of Stylistic Design. Journal of Contemporary Urban Affairs, 1(1), 44-55, 2017. https://doi.org/10.25034/1761.1(1)45-55

[34] A.F. Mokunfayo \& A.M. Babatunde. The Impact of Peri-Urbanisation on Housing Development: Environmental Quality and Residents' Productivity in Ibeju-Lekki, Lagos. Journal of Contemporary Urban Affairs, 2(2), 60-70, 2018. https://doi.org/10.25034/ijcua.20 18.3671

[35] Group, W. H. O. Q. O. L. Development of the WHOQOL: Rationale and current status. International Journal of Mental Health, 23(3), 24-56, 1994. https://doi.org/10.1080/002074 11.1994.11449286

[36] A. Mobaraki. Strategies for Mitigating Urban Heat Island 
Effects in Cities: Case of Shiraz City Center (Doctoral dissertation, Eastern Mediterranean University), 2012. http://i-rep.emu.edu.tr:8080/xmlui/bitstream/handle/11129/ 223/Mobaraki.pdf?sequence $=1$

[37] H. Barton, M. Grant \& R. Guise. Shaping neighbourhoods: a guide for health, sustainability and vitality. Taylor \& Francis, 2003. https://doi.org/10.4324/9780203986882

[38] J. Yoon \& J. Park. Comparative analysis of material criteria in neighborhood sustainability assessment tools and urban design guidelines: Cases of the UK, the US, Japan, and Korea. Sustainability, 7(11), 14450-14487, 2015. https://doi .org/10.3390/su71114450

[39] M. Carmona, T. Heath, S. Tiesdell \& T. Oc. Public places, urban spaces: the dimensions of urban design. Routledge, 2010. https://doi.org/10.4324/9781856179041

[40] M. Carmona \& L. Sieh. Measuring quality in planning: managing the performance process. Routledge, 2004. https://doi.org/10.4324/9780203563311

[41] M. Jenks \& C. Jones (Eds.). Dimensions of the sustainable city (Vol. 2). Springer Science \& Business Media, 2009.

[42] M. Nikoofam. Questioning Accessibility of Disable People at Sea Front, Case Study: Kyrenia \& Laguna Sea Fronts in North Cyprus (Doctoral dissertation, Eastern Mediterranean University, 2013.

[43] R. Rahbarianyazd \& N. Doratli. Assessing the contribution of cultural agglomeration in urban regeneration through developing cultural strategies. European Planning Studies, 25(10), 1714-1733, 2017. https://doi.org/10.1080/09654313 .2017 .1317721

[44] J. Lang. Urban design: The American experience. John Wiley \& Sons, 1994. https://doi.org/10.5860/choice.31-5834

[45] M. Nikoofam \& A. Mobaraki. Improving the quality of affordable housing: The case of Mara in Famagusta City, North Cyprus, Turkey. Recent Advances in Engineering Mechanics, Structures and Urban Planning, 2013. http://www.wseas.us/e-library/conferences/2013/Cambridge UK/STUPEME/STUPEME-01.pdf

[46] A. Walker \& L. Van der Maesen. Social quality and quality of life. In Challenges for quality of life in the contemporary world (pp. 13-31). Springer, Dordrecht, 2004. https://doi.org/10.1007/978-1-4020-2903-5_2

[47] N.H. Boudjabi, F. Bouzahzah, A. Bouchareb, Urban Strategies for a Renewal of Algerian Cities: Constantine of Tomorrow. Civil Engineering and Architecture, 6(1): 18-24, 2018. https://doi.org/10.13189/cea.2018.060102
[48] M. Karmilah, M., \& A.Y. Puspitasari. The Impact of MCK+ Prangkuti Luhur towards the Improvement of Community Life Quality in Bustaman Village. Journal of Contemporary Urban Affairs, 4(2), 59-66, 2020.https://doi.org/10.25034/ij cua.2020.v4n2-6

[49] R. Qawasmeh. Identification of the quality of urban life assessment aspects in residential neighbourhoods in Doha. WIT Transactions on Ecology and the Environment, 191, 391-402, 2014. https://doi.org/10.2495/sc140331

[50] D. Oktay \& R. W. Marans. Overall Quality of Urban Life and Neighborhood Satisfaction: A Household Survey in the Walled City of Famagusta ${ }^{1}$. Open house international, 35(3), 27, 2010. http://www.openhouse-int.com/pdf/OHI\%20Vol. $35 \% 20$ No.3.pdf\#page $=28$

[51] H. A. Nia, R. A. Atun \& R. Rahbarianyazd. Perception based method for measuring the aesthetic quality of the urban environment. Open House International, 42(2), 11, 2017. https://doi.org/10.1057/udi.2015.25

[52] H. A. Nia \& R. Rahbarianyazd. Aesthetics of Modern Architecture: A Semiological Survey on the Aesthetic Contribution of Modern Architecture. Civil Engineering and Architecture 8(2): 66-76, 2020.https://doi.org/10.13189/cea .2020 .080204

[53] M. Fasli \& F. Pakdel. Assessing Laguna District's Spatial Qualities in Gazimagusa, Northern Cyprus. open house international, 35(1), 74, 2010. http://search.proquest.com/o penview/bafab99e1da4ed7795d41e3fec5607b8/1?pq-origsit $\mathrm{e}=\mathrm{gscholar} \& \mathrm{cbl}=456297$

[54] N. Doratli. A model for conservation and revitalization of historic urban quarters in Northern Cyprus. Unpublished Ph. D. thesis, Eastern Mediterranean University, Gazimagusa, Turkey, 2000. https://www.academia.edu/download/148047 56/doratlithesispdflast.pdf

[55] D. Oktay \& A. Rüstemli. Measuring the quality of urban life and neighborhood satisfaction: Findings from Gazimagusa (Famagusta) area study. International journal of social sciences and humanity studies, 2(2), 27-37, 2010. https://do i.org/10.1007/978-94-007-1742-8_10

[56] D. Oktay, A. Rüstemli \& R. W. Marans. Neighborhood satisfaction, sense of community, and attachment: Initial findings from Famagusta quality of urban life study. ITU A/Z Journal, 6(1), 6-20, 2009. http://www.academia.edu/downl oad/31266611/ITU_AZ_2009.pdf

[57] D. Oktay. An analysis and review of the divided city of Nicosia, Cyprus, and new perspectives. GEOGRAPHY-LONDON-, 92(3), 231, 2007. http://www.academia.edu/download/31266595/Geography_ 2007_92(3)_Oktay.pdf 